\title{
UPPER AND LOWER SOLUTIONS METHOD FOR HIGHER ORDER DISCRETE BOUNDARY VALUE PROBLEMS
}

\author{
Ravi P. Agarwal and Fu-Hsiang Wong
}

Abstract. We shall offer sufficient conditions on the function $f\left(i, u_{1}, \cdots, u_{n-1}\right)$, so that the higher order discrete boundary value problem

$$
(B V P)\left\{\begin{array}{l}
(E) \Delta^{n} u(i-1)+f\left(i, u(i), \Delta u(i), \cdots, \Delta^{n-2} u(i)\right)=0 \text { for } i \in[1, T+1] \text { and } n \geqslant 2, \\
(B C)\left\{\begin{array}{l}
\Delta^{m} u(0)=0,0 \leqslant m \leqslant n-3, \\
\alpha \Delta^{n-2} u(0)-\beta \Delta^{n-1} u(0)=0, \\
\gamma \Delta^{n-2} u(T+1)+\delta \Delta^{n-1} u(T+1)=0,
\end{array}\right.
\end{array}\right.
$$

has at least one solution.

\section{Mathematics subject classification (1991): 34B15, 39A10.} lower solutions.

\section{REFERENCES}

[1] R. P. AgARWAL, On boundary value problems for second order discrete systems, Applicable Analysis 20 (1985), 1-17.

[2] R. P. AgARWAL, Difference Equations and Inequalities, Marcel Dekker, New York, 1992.

[3] R. P. AgARWAL AND D. O'REGAN, Boundary value problems for discrete equations, Applied Mathematics Letters 10(4) (1997), 83-89.

[4] R. P. AGARWAL AND D. O'REgAn, A fixed point approach for nonlinear discrete boundary value problems, Computers Math. Applic., to appear.

[5] R. P. Agarwal And D. O'REgan, Singular discrete boundary value problems, Applied Mathematics Letters, to appear.

[6] R. P. AGARWAL AND D. O'Regan, Nonpositone discrete boundary value problems, Nonlinear Analysis, to appear.

[7] R. P. Agarwal and D. O’Regan, Difference equations in abstract spaces, J. Austr. Math. Soc., Ser.(A), to appear.

[8] R. P. AGARWAL AND F. H. WONG, Existence of positive solutions for higher order difference equations, Applied Mathematics Letters 10(5) (1997), 67-74.

[9] R. P. AgarWal AND F. H. Wong, Existence of positive solutions for non-positive difference equations, Mathl. Computer Modelling, to appear.

[10] R. P. AgARWAL AND F. H. WONG, An application of topological transversality to non-positive higher order difference equations, Appl. Math. Comp., to appear.

[11] R. P. Agarwal and P. J. Y. Wong, Advanced Topics in Difference Equations, Kluwer, Dordrecht, 1997.

[12] R. GAINES, Difference equations associated with boundary value problems for second order nonlinear ordinary differential equations, SIAM J. Numer. Anal. 11 (1974), 411-434.

[13] J. HENDERSON, Singular boundary value problems for difference equations, Dynamic Systems and Applications 1 (1992), 271-282. 
[14] J. HENDERSON, Singular boundary value problems for higher order difference equations, in Proceedings of the First World Congress on Nonlinear Analysts 1992, ed. V. Lakshmikantham, Walter de Gruyter and Co.,, 1996, pp. 1139-1150.

[15] A. LAsotA, A discrete boundary value problem, Ann. Polon. Math. 20 (1968), 183-190.

[16] A. C. PETERSON, Existence and uniqueness theorems for nonlinear difference equations, J. Math. Anal. Appl. 125 (1987), 185-191.

[17] P. J. Y. WONG AND R. P. AGARWAL, On the existence of solutions of singular boundary value problems for higher order difference equations, Nonlinear Analysis 28 (1997), 277-287.

[18] P. J. Y. WONG AND R. P. AgaRWaL, Topological Methods in Nonlinear Analysis, to appear.

[19] P. J. Y. WONG AND R. P. AGARWAL, On the eigenvalues of boundary value problems for higher order difference equations, Rocky Mountain J. Math., to appear.

[20] W. ZhuAnG, Y. ChENG AND S. S. Cheng, Monotone methods for a discrete boundary value problem, Computers Math. Applic. 32 (1996), 41-49.. 